\title{
Systems of environmental innovation: sectoral and technological perspectives on ballast water treatment systems
}

\author{
Teemu Makkonen $^{1}$ (D) $\cdot$ Tommi Inkinen $^{2}$ (D)
}

Received: 21 October 2020 / Accepted: 5 January 2021 / Published online: 21 January 2021

(C) The Author(s) 2021

\begin{abstract}
The research on innovation in the maritime sector has commonly focused on the implementation of innovation rather than on more complex issues such as the interplay between technological aspects, market conditions, and, particularly, regulatory regimes in shaping the emergence and growth of global systems involved with the development, production, and use of environmental innovation. Therefore, this paper sets out to analyze - by combining insights from sectoral (SSI) and technological (TIS) systems of innovation concepts - ballast water treatment systems (BWTS), designed to prevent the negative impacts of invasive species, as an example of such complex interaction. The results show how public policy and institutional acceptance have shaped the market for BWTS. First, BWTS were induced by environmental regulations mandating their use. Second, the demand for BWTS increases substantially when the implementation date of the regulations approaches. Third, differences in regulatory regimes shape the demand for various available technologies. Without coordinated regulations, this unclear operating environment remains a definite concern for shipowners when choosing the specific type of BWTS technology for onboard installation. The results also underline that the combined SSI/TIS framework, utilized in this paper, is a feasible analytical framework for studying environmental innovation.
\end{abstract}

Keywords Ballast water management · Ballast water treatment systems · Environmental innovation $\cdot$ Public policy $\cdot$ Sectoral systems of innovation $\cdot$ Technological systems of innovation

Teemu Makkonen teemu.makkonen@uef.fi

1 Karelian Institute, University of Eastern Finland, P.O. BOX 111, FI-80101 Joensuu, Finland

2 Department of Geography and Geology, University of Turku, Turku, Finland 


\section{Introduction}

As stated by Shi et al. (2018: p. 863), "there have been growing concerns on the environmental impacts of maritime transportation, which have attracted great attention from both academia and practitioners." The environmental impacts of ballast water are among these pressing concerns. Ballast water is essential to keep ships' stability and trim to ensure the vessel's seaworthiness. As a result, water is being moved as ballast from one area to another (Rivas-Hermann et al. 2015). This water might contain nonindigenous invasive species (Flagella and Abdulla 2005) that, when introduced into a new habitat, can have negative economic and health impacts and, particularly, place severe ecological strain to the local marine ecosystem and adjacent coastal regions. Therefore, the International Maritime Organization (IMO) has set up regulations, namely the "Ballast Water Management Convention" (BWMC), to prevent these types of environmental crisis. BWMC mandates that before releasing the ballast water to the sea, ships need to clean it (David and Gollasch 2015, 2018).

As stated by $\mathrm{Hu}$ and Liu (2019: p. 1739): "global environmental problems will require the development of new technologies." Thus, also BWMC created a need for new technologies that are able to clean the ballast water, commonly referred to as "ballast water treatment systems" (BWTS) or "ballast water management systems" (BWMS) (IMO 2019a), of which we have chosen to use the former. BWTS technology aims at reducing the negative environmental impacts of shipping by preventing invasive species from spreading, which is a major threat to global biodiversity (Bax et al. 2003). As such, BWTS have been described as a text-book example of environmental innovation induced by more stringent environmental regulations (Rivas-Hermann et al. 2015; Lam and Chang 2019; Raza 2020). Moreover, BWTS constitute a significant market globally. BWMC entered into force in September 2017 (12 months after ratification by a minimum of thirty countries representing at least $35 \%$ of the global merchant fleet as stated in Article 18 of the convention). By the end of 2019, according to IMO (2019b), 81 countries had already ratified BWMC (Fig. 1). This constitutes a global market of ca. 70.000 vessels - accounting for (in tonnage) over $80 \%$ of the global merchant fleet - to be fitted with BWTS and adding up to an estimated turn-over of 50-74 billion US dollars for their installation (excluding maintenance) (King et al. 2012). Additionally, environmental technologies have been at the heart of the green growth strategies of countries and, e.g., the European Union for the last decade (European Commission 2010). Therefore, there is also a significant policy interest on environmental innovation of which BWTS is an example of.

The literature on innovation in the maritime sector has generally focused on the implementation rather than on the development phase (Koukari and Tei 2020). Relatedly, the research on BWTS has commonly approached the issue one-sidedly as a technical problem comparing the costs and efficacy of different technologies utilized in BWTS (e.g., Stehouwer et al. 2015; Batista et al. 2017; Wang and Corbett 2020) - to ease the decision-making processes of shipowners contemplating on which BWTS to install onboard-while paying lesser attention to the wider economic and social implications of this environmental innovation. That is, to date, there are no systematic investigations into the systemic nature of this environmental innovation that would combine the commonly studied technological aspects of BWTS with an analysis of the policy "push" that paved the way for their development and the market demand for this 


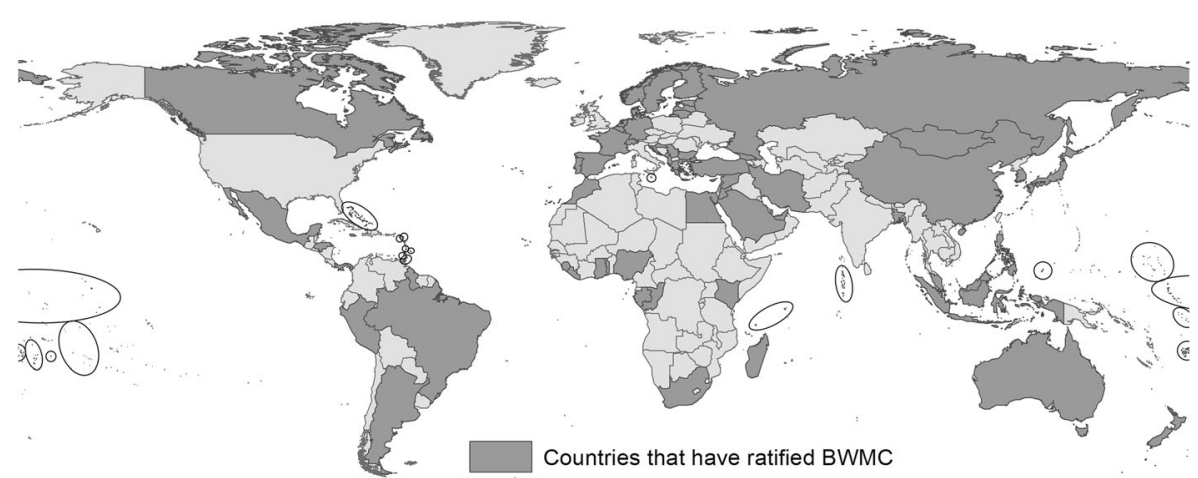

Fig. 1 The countries that had ratified BWMC by the end of 2019. Source: based on data from IMO (2019b)

group of technologies facilitating sustainable development, a research gap that this paper seeks to address by answering the following research questions:

1. What knowledge base is BWTS technology built upon?

2. What role did market demand play in the development of BWTS technology?

3. What role did public policy play in the development of BWTS technology?

Earlier studies on environmental innovation, or its close synonyms "eco-innovation," "sustainable innovation," and "clean-tech innovation," have commonly approached the issue either through the literature on sectoral (SSI) (Galliano and Nadel 2015) or technological (TIS) (Gosens et al. 2015) systems of innovation. Makkonen and Inkinen (2018) have noticed similarities between these two approaches (notably their focus on explaining system dynamics through knowledge bases or technological regimes, market formation and demand as well as institutional and policy support), combined them into a unified conceptual framework and argue that the resultant joint SSI/TIS framework is a helpful tool for studying environmental innovation. The evidence on the feasibility of their synthesized framework, however, still rests on a single case study example (marine scrubber systems) presented in their paper. Thus, here the feasibility of their framework is tested by extending their original work on marine scrubber systems into a different technological context to see whether the approach can be applied beyond its original context or not and whether its conceptual description needs redefining by posing the final research question:

4. Does the combined SSI/TIS framework work as an analytical basis for investigating the development of environmental innovation?

\section{Systems of environmental innovation: sectoral and technological}

\subsection{Environmental innovation}

Innovation is traditionally considered as products, processes, solutions, practices, or ideas that have an impact on efficiency, profitability, or value (Gopalakrishnan and 
Damanpour 1997; Makkonen et al. 2013). Thus, traditionally it has been considered that innovation always has a financial impact on the organization adopting it into their operations or production. However, more recently new approaches have emerged. These include environmental innovation (also other terms, such as eco-, clean-tech and sustainable innovation, are commonly used) that may be, e.g., considered from the point of view of diminishing emissions either with or without potential for market gains. While voluntary developments for increased sustainability do happen, environmental innovation is (more) commonly introduced as a response to legislative changes in environmental regulations as reported, e.g., by Makkonen and Repka (2016) in the case of the IMO enforced Sulphur regulations' impact on the birth of the market for marine scrubber systems.

\subsection{Sectoral systems of innovation}

The sectoral systems of innovation (SSI) approach, conceived into the literature by Malerba (2002), divides the system, focused on a certain industry sector, into three distinct parts (or building blocks):

1. SSI requires recognition of technological regimes under which firms operate. A widely used division separates (1) an entrepreneurial regime that is characterized by emergence and disappearance of innovative start-ups and small-sized companies - i.e., competitive market conditions - and its direct opposite (2) a routinized regime that is unfavorable towards new entrants, since the innovative activities are dominated by few established corporations with large R\&D departments-i.e., oligopoly market conditions (Malerba and Orsenigo 1997; Marsili 2002).

2. Market demand shapes the dynamics of SSI. While economies of scale can lead to periods characterized by dominant designs and monopolistic market conditions with (only) incremental improvements, groups of niche consumers (such as green consumers) willing to experiment and adopt new (sustainable) technologies can support radical innovation (i.e., disruptive innovation that creates a new market replacing the dominant technology) by testing the technology and by signaling interest that helps in predicting the likely market demand for the novel product or service (Malerba et al. 2007; Oltra and Saint Jean 2009; Robbins and O'Gorman 2015).

3. SSI are impacted by public policy. This is particularly important in the case of environmental innovation, since market demand alone might not be strong enough to incentivize companies to invest on their development. As such, policies are needed to strive the industry towards more sustainable practices. These policies can be aimed at increasing the payoff of successful innovation (e.g., through environmental regulations) or reducing the costs of developing them (e.g., tax credits and $\mathrm{R} \& \mathrm{D}$ funding). Commonly, both types of policies are utilized leading to an "environmental innovation policy mix" designed at varying geographical scales: international, national, or regional (Oltra and Saint Jean 2009; Makkonen and Repka 2016).

Oltra and Saint Jean (2009: p. 579) have concluded that the SSI approach provides a feasible tool to understand the technological determinants of environmental innovation 
and "the factors affecting their competitive dynamics" leading potentially to "more integrated and dynamic view of environmental and innovation policy".

\subsection{Technological systems of innovation}

The technological systems of innovation (TIS) approach, introduced into the literature by Carlsson and Stankiewicz (1991), focuses on the innovation development of a certain technology. TIS dynamics are normally divided into seven key processes, termed as "functions" (Hekkert et al. 2007; Bergek et al. 2008; Makkonen and Inkinen 2018):

1. The starting point is the identification of knowledge development and diffusion that defines the knowledge base, i.e., the types, sources, and transfer of knowledge, required for the development of various technological alternatives to cater for the needs of the TIS.

2. Selectable technological alternatives (available technologies), articulation of interest from customers and regulatory pressures giving companies incentives to enter the market, have an influence on the direction of search in the selection process for the most suitable environmental innovation within the TIS.

3. Entrepreneurial activity and experimentation - relating to knowledge mobilization where firms turn knowledge into concrete actions by involving pioneering experimenters to test the new technology and, subsequently, introducing various technological applications into the market - is a necessary process in the development of the TIS (there needs to be market transactions for a TIS to exist).

4. The growth potential of the TIS is largely determined by market formation through three steps of market evolution: (i) the nursing market phase for niche products where early experimental products are released to the market; (ii) the most successful products reach the bridging market phase with significant volumes of market transactions and; (iii) finally, the TIS evolves into a mature market phase commonly including only a limited number of competing products (dominant designs) with mass market potential.

5. The above processes are fundamentally intertwined with legitimation, i.e., customer acceptance and, in the case of environmental innovation especially, institutional acceptance of emerging new technologies, that creates the demand for and, particularly, "certifies" the suitability of distinct technological alternatives in meeting, e.g., the emission limits set by environmental regulations.

6. Successful resource mobilization in terms of partnerships (e.g., customers as cocreators), availability of human capital (e.g., attracting high-skilled workers), and financial support systems (e.g., R\&D funding from the government) further reinforces the TIS.

7. Finally, the resources (human capital, networks, etc.) of the firms entering the TIS will lead to the emergence of positive externalities in terms of knowledge spillovers. These externalities will strengthen the TIS and lead to further technological

\footnotetext{
${ }^{1}$ The number and content of included "functions" vary between different studies on TIS (see, e.g., Geels et al. 2008). Here we follow Makkonen and Inkinen (2018) and utilize these seven commonly identified key processes.
} 
developments in the form of incremental improvements and specialized products or even new technological solutions that alter the existing market conditions radically (i.e., disruptive innovation, see Hämäläinen and Inkinen 2019; Yigitcanlar and Inkinen 2019) and potentially challenge and change the way how the whole TIS operates.

Jacobsson and Bergek (2011) have demonstrated the ability of the TIS framework to contribute to the study of environmental innovation by facilitating the identification of the aspects (functions) where policy interventions are likely to matter the most for sustainable development.

\subsection{Combined SSI/TIS framework}

Figure 2 presents the connecting elements between the SSI and TIS concepts. Both innovation system schematics are interlinked, and their main differences are related to the treatment of sectoral boundaries: SSI approach is sector specific while TIS, centered around a certain technology, commonly cross sectoral boundaries (Markard and Truffer 2008). The concrete connections between the approaches can be summarized as follows (Makkonen and Inkinen 2018):

1. Technological regimes of the SSI relate to TIS's knowledge development and diffusion (via the knowledge base of the industry); influence of the direction of search (via the available technologies in other related industries); entrepreneurial activity and experimentation (via the mobilization of knowledge into concrete action by the pioneers developing the technology); and resource mobilization (via the available human capital inherent in the industry).

2. Market demand of the SSI relates most obviously to TIS's market formation (i.e., market evolution) but also to influence of the direction of search (via the articulation of interest towards the technology); entrepreneurial activity and experimentation (via pioneering experimenters willing to test the technology); legitimation (via the acceptance of the technology by the customers); and resource mobilization (via partnerships to develop the technology together with the producers).

3. Public policy of the SSI relates to TIS's influence of the direction of search (via regulatory pressures mandating certain standards for the technology); legitimation (via the acceptance that institutions give to available technologies); and resource mobilization (via financial support systems to develop and test the technology).

Finally, the interplay of these processes leads to the emergence of positive externalities including, e.g., knowledge spillovers that benefit the technological regime of the system.

As seen from Fig. 2, while the SSI approach focuses on industrial sectors and the TIS approach on distinct technologies, the two overlap in several aspects. In the literature on environmental innovation, the choice between the two concepts has traditionally been done based on the research subject. That is, whether the focus is laid on the whole sectors (SSI) or on a distinct innovative technology (TIS). Additionally, the concept of clusters is often used to analyze geographically bound SSI (Cooke 


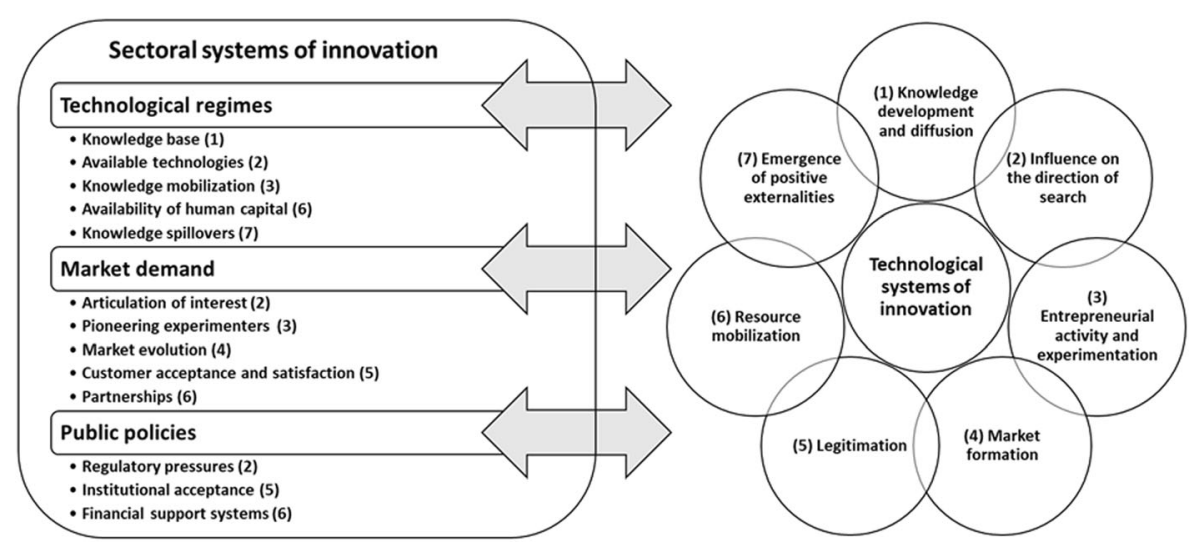

Fig. 2 The combined SSI/TIS framework (numbers in brackets indicate the links descripted in the text). Source: modified from Makkonen and Inkinen (2018)

2002; Makkonen et al. 2013). BWTS, selected here as the case study example is (as will be shown below), however, neither a distinct sector (such as the maritime sector) nor a specific technology but rather a "family" of competing solutions. Additionally, BWTS production and use is not bound only to certain geographical locations but is global in its very nature as maritime transport related environmental issues and innovation designed to mitigate them commonly are. Thus, while still rarely applied, the benefit of combining the two innovation system concepts into an overarching framework stems from its ability to consider simultaneously both the sectoral as well as the technology-specific perspectives of the innovation under investigation.

According to Makkonen and Inkinen (2018), SSI and TIS have similarities particularly concerning public sector interventions (either positive or negative): i.e., in terms of public policies or legitimation. A main challenge in considering policy issues focusing on environmental innovation and sustainability is that a mixture of tools is needed to achieve the correct balance of (positive) incentives and (negative) penalties (Oltra and Saint Jean 2009). The mixture also includes a geographical dimension, as environmental issues are essentially global (Köhler 2014). Thus, spatial scales matter. In the case of the maritime sector, organizations such as IMO play a significant role in global regulative policy guidance (Makkonen and Repka 2016). Nevertheless, the overlapping amount of spatially bound jurisdictions-regional, national, and international-causes uncertainties into the policy implementation. Therefore, the balancing between these uncertainties by finding optimal policy tools can lead to the emergence of environmental innovation.

\section{Study design}

The purpose of this paper is to present, analyze, and interpret the interplay between technological aspects, market conditions, and, particularly, regulatory regimes in shaping the emergence and growth of a global system involved with the development, production, and use of environmental innovation. For this purpose, a desk study 
approach was considered to be the most suitable option (in line with, e.g., Laaksonen and Mäkinen 2013), since it enables a selection of diverse data sources. The utilized data were collected in January 2020 and combines:

- Existing academic literature on BWTS (literature searches with terms, such as, BWMC, BWTS, and BWMS in Scopus and Google Scholar databases):

- The initial literature screening results were assessed by reading the abstracts of the potential literature (mainly articles) to exclude the ones that did not discuss BWTS (or discussed them only narrowly via, e.g., cost-efficiency analysis) - the most relevant papers found via this literature search are cited in the Results section.

- Policy documents regarding ballast water regulations:

- Policy documents and related reports were sourced from the document databanks of the European Union, IMO, US Maritime Administration, US Coast Guard, and the United Nations (UN).

- Technical descriptions of the varying technologies applied to clean ballast water as reported by BWTS suppliers:

- Collected from company, such as Alfa Laval and Wärtsilä, webpages

- Market data on the demand for BWTS gathered from international organizations, classification societies, and market research companies:

- Including Ballast water Equipment Manufacturers Association, DNV GL, Marine Insight, Clarksons Research, Seatrade Informa Markets, and the UN

Following a standardized thematic content analysis of textual data (see, e.g., Silverman 2016), the collected material was screened by the first author and the text was coded under the three main themes discussed in the SSI/TIS framework: (1) technology, (2) market demand, and (3) policy. The processed data were then analyzed by both authors to identify similarities and differences between various data sources and ultimately utilized to draw conclusions that provide answers to the research questions posed in the Introduction section. That is, following the combined SSI/TIS framework proposed by Makkonen and Inkinen (2018), this data allows to uncover the interplay between the building blocks of SSI and the functions of TIS as shown by the identified connections that link the two concepts together and that have led to the development of BWTS (see Fig. 3). Essential connections are drawn between public policy (regulations), market demand (corporate logic and responsibility), and technological regime (innovation and clean tech). The technology solutions (e.g., UV irradiation, heat or ozone treatment, etc.) are based on knowledge development and diffusion that are fundamental in the SSI/TIS framework and in the development of BWTS depicted in Fig. 3. Based on this conceptual analysis conclusions may be drawn (1) on the emergence (knowledge base and environmental regulations) and development (evolution of market demand and institutional acceptance) of the sectoral and technological systems of environmental 


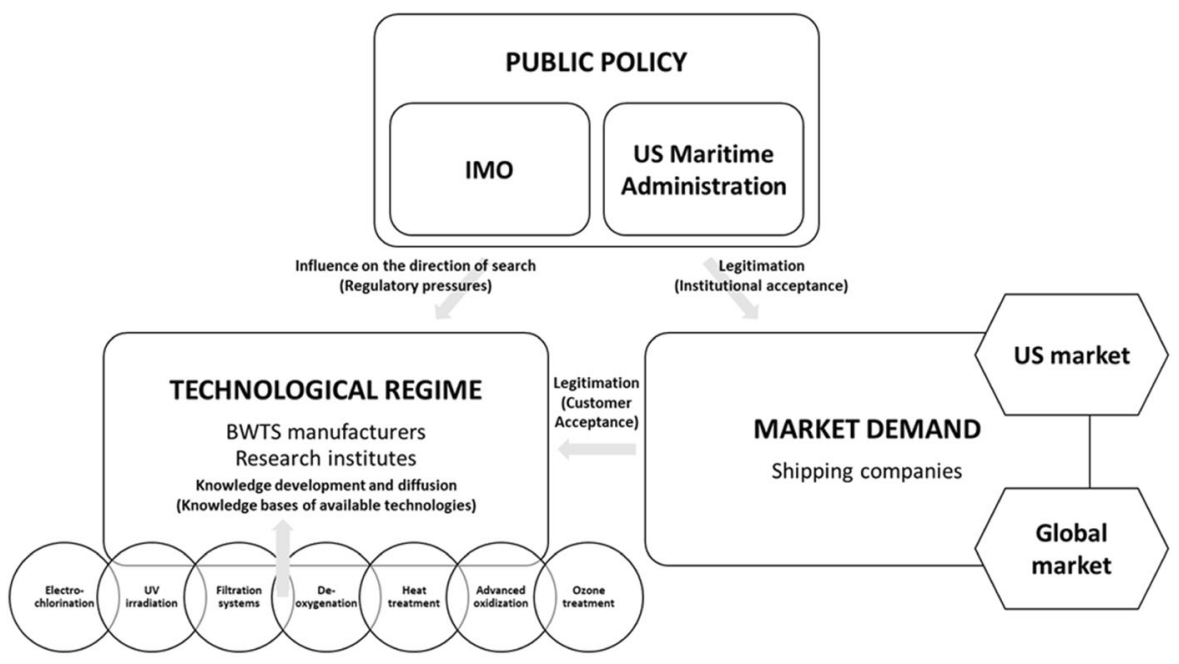

Fig. 3 The building blocks of SSI and the main interlinkages to the functions of TIS in the case of BWTS

innovation centered around BWTS technologies and (2) on the feasibility of the joint SSI/TIS approach.

\section{Empirical case: ballast water treatment systems}

\subsection{Public policy}

After many years of complex negotiations between IMO member states, BWMC was finally approved in 2004 and enforced in 2017. The initial "Guidelines for Approval of BWMS" were revised in 2016. These new guidelines were adopted as a mandatory code in 2018 and entered into force in 2019 (IMO 2019a). New builds need to have BWTS installed, while existing vessels were given a time window, until 2024, for retrofitting BWTS (DNV GL 2019a). BWMC, thus, lays regulatory pressures (influence on the direction of search) to the shipping industry by compelling ships to have a BWTS installed onboard that can meet the specific size-class discharge standards (D-2 standard ${ }^{2}$ ) presented in Table 1 . That is, under Regulation D-3, ${ }^{3}$ these standards must be met by BWTS manufacturers in order for them to achieve an "official type approval" for the applied technology (Batista et al. 2017; David and Gollasch 2018). To facilitate the implementation of BWMC, IMO has also created positive incentives by financially supporting (resource mobilization) innovative global partnerships to develop solutions to the ballast water problem through projects such as the GloBallast program (IMO 2019c). At the same time, the program aimed at facilitating knowledge and information exchange to induce the emergence of positive externalities. There are also examples of

\footnotetext{
${ }^{2}$ The D-1 Standard, i.e., the Ballast Water Exchange (BWE) Standard, refers to open sea exchange of ballast water (Gerhard et al. 2019). It has numerous shortcoming related to, e.g., ecological risks (regrowth, harmful algae, etc.) (see Scriven et al. 2015 for a more detailed account) and vessel safety (loss of stability) and is, thus, being phased out by 2024 in favor of the D-2 Standard.

${ }^{3}$ Regulation D-3 requires ships to comply to IMO guidelines and use type approved BWTS.
} 
Table 1 Biological limits to ballast water discharges. Source: IMO (2004)

Target organisms

Size $\geq 50 \mu \mathrm{m}$

Size $\geq 10 \mu \mathrm{m}<50 \mu \mathrm{m}$

Vibrio cholerae (serotypes O1 and O139)

Escherichia coli

Enterococci
Concentration in the ballast water discharge

$<10$ viable organisms per cubic meter

$<10$ viable organisms per milliliter

$<1$ (CFU) per $100 \mathrm{~mL}$

$<250$ (CFU) per $100 \mathrm{~mL}$

$<100(\mathrm{CFU})$ per $100 \mathrm{~mL}$

$C F U$, colony-forming units

funding programs, such as ballast water technology demonstration program ${ }^{4}$ funded by the US Maritime Administration (among others), that have provided grants for startups and, thus, support entrepreneurial activity and experimentation.

US Maritime Administration has, however, developed its own regulations enforced by the US Coast Guard (USCG) and the Environmental Protection Agency (hereafter referred simply as USCG) to ships operating in US waters, without any immediate plans, according to Batista et al. (2017), to become a signatory country of IMO BWMC. That is, the USA is not part of BWMC but has its own national regulations ${ }^{5}$ regarding ballast water. As a result, there are, in fact, two influential regulatory regimes for BWTS technologies: the one set by IMO (designed for ships ${ }^{6}$ involved in international trade and implemented by countries that have signed BWMC) and the one set by USCG, in 2012, in their "Final Rule entitled Standards for Living Organisms in Ships' Ballast Water Discharged in US Waters." The Final Rule mandates all ships that operate in US waters to comply to the regulations by having BWTS installed by the beginning of $2021^{7}$ (new builds have had to comply since 2014). The two regulatory regimes are generally aligned but do have differences (a detailed account of the similarities and differences can be found in Čampara et al. 2019).

The most significant difference between the IMO and USCG regulations relates to the testing and verification, i.e., institutional acceptance (legitimation), of the efficacy of BWTS to comply to the discard standards set in D-2 contra the ones set by USCG. Notably, while IMO defines their limits according to the number of "viable" organisms (cf. Table 1), i.e., organisms that can successfully reproduce, USCG only makes a distinction whether the organisms are living or dead (Čampara et al. 2019). According to Cullen (2018: p. 1634), there are "two fundamentally different methodologies that have been employed for enumerating potentially invasive organisms" for BWTS type approval testing: (1) stain-motility (S-M) and (2) most probable number (MPN). Research has shown evidence that the efficacy of MPN method is as efficient as S-M for verifying that BWTS meet the standards for type approval (Blatchley et al. 2018;

\footnotetext{
${ }^{4}$ For a presentation, see: https://greatlakes-seaway.com/wp-content/uploads/2019/10/Ballast_Water_ Technology_Demonstration.pdf

${ }^{5}$ Furthermore, individual US States can implement their own regulations concerning ballast water management.

${ }^{6}$ Excluding ships operating in territorial waters of their flag states, ships with permanent or sealed ballast, warships and ships that discharge their ballast water to approved onshore reception facilities (Čampara et al. 2019).

${ }^{7} \mathrm{BWE}$ is not accepted by USCG beyond 2021.
} 
Cullen 2018), but there is a fundamental difference between the two methods. MPN measures organisms' ability to reproduce and not whether they are alive or dead. Therefore, while IMO considers both as valid tools for testing BWTS efficacy, USCG rejected MPN as an evaluation method in 2016. As a result, USCG type approval process is more stringent compared to IMO type approval procedures.

USCG has accepted (as stated in the Final Rule) IMO type approved BWTS, termed "alternative management systems" (AMS), as a temporary option (up to a period of 5 years) and a bridging measure allowing sufficient time for BWTS manufacturers to acquire type approval from USCG until they are available widely enough. In some cases, shipowners have been granted extensions to provide them reasonable flexibility because USCG type approved BWTS are not yet available on the market. However, AMS is not an alternative when suitable USCG type approved BWTS are available. Furthermore, it is anticipated that no further extensions will be granted after the beginning of 2021 (Čampara et al. 2019). These differences between the regulatory regimes create difficulties for stakeholders attempting to conform to regulations (Gerhard et al. 2019), and as such affect the market formation for BWTS depending on the area of operations of the shipping companies.

\subsection{Technological regime}

As there are no pre-set methods to comply to D-2 standard, manufacturers have developed a variety of different approaches: already in 2017 more than 60 BWTS had been given a type approval, under Regulation D-3, by IMO (IMO 2017; Gerhard et al. 2019). As of December 2019, according to the list of type approvals for BWTS that are in accordance with IMO guidelines, this figure had risen to 83 (IMO 2019a). As such, there are different technological solutions available to meet the requirements set by IMO in BWMC (Bowmer and Linders 2010; Veldhuis et al. 2010). Many of these technologies applied in BWTS are already in extensive use in municipal and industrial water treatment applications (Gerhard et al. 2019). Thus, as in the case of marine scrubber systems (Makkonen and Inkinen 2018), the technological regime of BWTS is built upon the existing knowledge base (knowledge development and diffusion) of similar available technologies (influence on the direction of search) on land. However, while BWTS employs existing technologies, designing these technologies to fit the relatively small spaces of ships has, nonetheless, been a significant engineering achievement (Davidson et al., 2017) resting on the shoulders of entrepreneurial firms ${ }^{8}$ willing to mobilize this knowledge into actual products (entrepreneurial activity and experimentation). This achievement has been accomplished, particularly, with the human capital (resource mobilization) of companies (such as Alfa Laval and Wärtsilä) specialized on both land and marine equipment manufacturing. Additionally, the public sector is also involved in the technological regime, since government-owned research institutes, such as the VTT Technical Research Centre of Finland, have early-on taken a proactive role in the knowledge development and diffusion of available BWTS technologies via research and development projects (e.g., Sassi et al. 2005).

\footnotetext{
${ }^{8}$ At the time of the writing, Ballast water Equipment Manufacturers Association (BEMA) had 17 charter member companies and 15 associate members (BEMA 2019), but the number of companies with IMO/USCG type approved BWTS is higher.
} 
As such, BWTS can be considered an adaptation of existing technologies to fit new purposes rather than something radically new. At the same time, the technology is an "end-of-pipe" solution since it deals with the symptoms but not the cause of the problems related to the use of ballast water. However, it has to be noted that - while emerging new solutions are being continuously developed - at the moment there really are no viable alternatives for the use of ballast water, in ensuring the vessel's seaworthiness in terms of trim and stability.

At the moment there is no single technology that would be superior to the others in terms of economic feasibility and cleaning efficiency but according to, e.g., Batista et al. (2017) the two main technologies utilized are as follows: (1) electrolytic (electrochlorination) and (2) ultraviolet (UV) irradiation. The other "less common" types of BWTS available on the market are the following (Gerhard et al. 2019): (3) filtration systems, (4) deoxygenation, (5) heat treatment, (6) advanced oxidization, and (7) ozone treatment.

While sufficiently effective to comply with the IMO D-2 standard (Stehouwer et al. 2015), none of the BWTS technologies is superior in their performance nor totally problem-free (Batista et al. 2017; Gerhard et al. 2019; Marine Insight 2019). Rather, the availability of various BWTS technologies helps to guarantee their suitability for different vessel types (e.g., in terms of size) and different environmental circumstances (e.g., in terms of salinity) (Davidson et al. 2017). Moreover, the market for developing BWTS is a dynamic one, with apparent knowledge spillovers (emergence of positive externalities) between different manufacturers, where newly proposed solutions are appearing nearly every month (David and Gollasch 2015). Thus, the leading role of electrolytic and UV technologies is not guaranteed in the future. Given the above, the technological regime of BWTS resembles the entrepreneurial regime discussed in the literature on SSI.

\subsection{Market demand}

The market for BWTS is heavily affected by public policy (King et al. 2012). As in the case of marine scrubber systems (Makkonen and Inkinen 2018), it took some years after the approval of the IMO regulations in 2004 before the first (type approved) BWTS were introduced into the market (IMO 2019a): BWTS were induced by environmental regulations. Similarly, the implementation of the ballast water regulations coincides with a significant increase in the share of ships fitted with BWTS (Gerhard et al. 2019). Thus, despite there were a few pioneering experimenters (entrepreneurial activity and experimentation) (Davidson et al. 2017), it was only closer to the implementation dates set by IMO and USCG that BWTS really gained a significant increase in their market demand (market evolution or market formation) after which there has been a steady (cumulative) growth in the number of ships that have installed BWTS onboard (Gerhard et al. 2019). At the beginning of 2017, 5.3\% of the global fleet had BWTS installed (Clarksons Research 2017). In 2 years, this figure had risen to $7.7 \%$ at the beginning of 2019 (UNCTAD 2019). There is still a potential demand of roughly 25,000-30,000 ships that need to be retrofitted with BWTS with an expected peak in demand in 2022 (Clarksons Research 2017; DNV GL 2019b). Due to the earlier implementation date $(2021)$ by USCG, the peak in the demand for retrofitting BWTS on ships operating in US waters will be reached earlier. The 
estimated overall expense of installing BWTS ranges from half a million up to three or even five million US dollars depending on the ship age, type, size, etc. (Čampara et al. 2019; DNV GL 2019b). Retrofitting BWTS, naturally, induces considerably higher costs than installing them on new builds (Davidson et al. 2017). BWTS add costs for shipowners also in the form of maintenance and operation (Gerhard et al. 2019).

The case of ships operating in US waters underlines the importance of legitimation in directing market demand for environmental innovation to certain available technologies. The initial market demand for BWTS in ships operating in US waters was, under the AMS exception (first BWTS were type approved by USCG in 2016), directed to several available technologies. Out of these technologies, UV was the category that had the most type approved BWTS (Table 2) and also the most common type of BWTS technology installed on ships, since the number of installed BWTS technologies align with the numbers of type approved BWTS per category (Davidson et al. 2017). However, as noted by Batista et al. (2017: p. 4) "UV irradiation does not immediately kill many microorganism types" and, thus, instant mortality is not induced directly even though the organisms are not viable. Therefore, MPN was a preferred testing methodology for UV-based BWTS (Gerhard et al. 2019). However, the decision of USCG to reject MPN as an evaluation method in 2016 has significantly hampered the approval of some UV-based BWTS (Batista et al. 2017). It has led to uncertainties considering the efficacy of many UV systems and, thus, negatively affected the customer acceptance (legitimation) of UV-based BWTS; while UV systems are still common notwithstanding the uncertainty, there is a clear decline in the number of vessel arrivals to US ports with UV-based BWTS after MPN was rejected by USCG (Gerhard et al. 2019).

The relatively high number of different available BWTS technologies (Table 2) reflects the articulation of interest (influence on the direction of search) from the market. Therefore, BWTS manufacturers have been keen on developing their systems in partnership (resource mobilization) with shipyards and shipowners (Wärtsilä 2014; Seatrade Informa Markets 2020). That is, the commercial appeal of this environmental innovation is high (as shown, e.g., by the number of ships that need to install BWTS in the near future) and companies are competing for market shares (Davidson et al. 2017).

Table 2 Number of BWTS type approved by IMO and USCG. Sources: Davidson et al. (2017); Gerhard et al. (2019); US Coast Guard (2019)

\begin{tabular}{|c|c|c|c|c|}
\hline \multirow[t]{2}{*}{ BWTS technology } & \multicolumn{2}{|c|}{ IMO type approved } & \multicolumn{2}{|c|}{ USCG type approved } \\
\hline & $2015^{*}$ & 2018 & 2018 & $2019 * *$ \\
\hline UV & 25 & 30 & 3 & $11[5]$ \\
\hline Electrolytic & 16 & 15 & 10 & $13[4]$ \\
\hline Advanced oxidation & 11 & 11 & & \\
\hline Ozone & 1 & 4 & & {$[2]$} \\
\hline Deoxygenation & 3 & 3 & & \\
\hline Filtration & 1 & 1 & & \\
\hline Heat & 1 & 1 & & {$[1]$} \\
\hline Total & 58 & 65 & 13 & $24[12]$ \\
\hline
\end{tabular}

*Accepted for use by USCG as AMS. **Number of BWTS pending for USCG type approval in brackets 
As stated by Gerhard et al. (2019) at the end of 2018, there were 65 IMO type approved BWTS - 83 in December 2019 (IMO 2019a)—but only 13 USCG approved ones. Thus far, only BWTS utilizing either UV (despite the rejection of MPN) or electrolytic processes have been approved by USCG. These BWTS technologies, naturally, counted for a vast majority of BWTS installed on board in ships arriving at US ports (Gerhard et al. 2019). According to recent figures, the situation has leveled off very recently as several UV-based BWTS have been granted USCG type approval (DNV GL 2019c; US Coast Guard 2019). Nonetheless, whereas UV is by far the most common technology used in IMO type approved BWTS, the same does not apply for USCG type approved BWTS (arguably duet to the rejection of MPN). Further, while two ozone and one heat based BWTS were pending for USCG type approval, the situation is still skewed towards the two dominant BWTS technologies. This naturally limits the market potential of the other "less common" types of BWTS.

The capacity of BWTS to meet the discharge standards set by USCG was an initial concern, explaining the low interest for BWTS installation prior to the first USCG type approved BWTS (Davidson et al. 2017), delaying the progress towards meeting ballast water regulations. Shipowners are, naturally, reluctant in taking a risk in installing BWTS that are not USCG type approved, while, as stated by Čampara et al. (2019 p. 12), "ships that have already installed IMO approved BWTS, that have been granted AMS status, can only hope that they will eventually be USCG type approved, otherwise, they will need to be replaced." Therefore, for ships operating in US waters, the subsequent low number of USCG type approved BWTS has posed a bottleneck for the delivery of these systems (Čampara et al. 2019).

\section{Summary and conclusions}

The main results of the analysis, following the combined SSI/TIS framework, can be summarized as follows (answering to research questions 1-3). BWTS were induced by environmental regulations (i.e., by regulatory pressures). BWTS are still a bridging market with competitive market conditions and without a dominant technology (or design). Rather, due to the high demand potential for BWTS, there are several competing technologies and manufacturers vying for market shares (Fig. 3). As such, the situation resembles that of an entrepreneurial regime with a steady "flow" of firms entering the market. While technological aspects (mainly build upon the knowledge base of available technologies used in other industries) of BWTS and their market conditions (including the pioneering experimenters who paved the way for customer acceptance and increased demand) have shaped and energized the sector, the importance of public policy pressures and legitimation (regulatory pressures and institutional acceptance) in the market evolution for environmental innovation needs to be stressed. Particularly, this study indicates that (Fig. 3):

1) The demand for BWTS grew significantly, for those BWTS that meet the regulations, only after the IMO and USCG regulations mandating their use after a predefined deadline came into force and

2) Due to the high costs of BWTS installation, customer acceptance has followed institutional acceptance. 
The first point is evidenced by the growth in the number of ships fitted with BWTS, while the second is demonstrated by the case of ships operating in US waters: the more stringent certification process, disfavoring (at least initially) particularly UV-based BWTS, enforced by USCG has led shipowners to favor a certain BWTS technology over others as shown by data on port arrivals (see Gerhard et al. 2019). That is, the various technological solutions behind BWTS need to be accepted by the institutions in charge before they attract significant market demand. As such, the differences between IMO and USCG regulatory regimes create an unclear operating environment with two separate market areas (Fig. 3), which remains a definite concern for shipowners unless a coordinated regulation between them can be created (see also Čampara et al. 2019).

In relation to the practical implications of this paper, when designing further environmental regulations policymakers should take into account that public policy and legitimation issues can, while inducing environmental innovation, also act as barriers for firms wishing to enter the market prompting for cooperation between regulatory regimes when defining environmental standards. For the business community, the paper highlights the importance of (1) recognizing regulatory demands proactively and (2) implementing (proactive) responses to strategic corporate responsibility planning, communications, and public relations. The recognition of the regulative impacts of environmental innovation (such as BWTS here) may motivate large shipping companies and ship builders to lead the way towards cleaner maritime industry. Finally, the applied SSI/TIS framework may help businesses to understand the utility of research-based planning as a tool to guide considerations of clean-tech alternatives, particularly in the case of long-term technology investments.

In relation to the academic implications of this paper and to answer to research question 4, it can be summarized that in practice the combined SSI/TIS framework is a feasible tool to investigate environmental innovation in sectors with several competing technologies as it helps to uncover their development (as discussed above) both from the sectoral as well as technological perspectives. However, and as already hinted by Makkonen and Inkinen (2018), the importance of the role played by public policy might have been understated in the original formulation of the combined SSI/TIS framework. The case of BWTS has, indeed, uncovered that in addition to the previously identified connections between public policy (in SSI) and the functions of TIS also new ones emerged: (1) public support for knowledge transfer facilitating the emergence of positive externalities (knowledge spillovers), (2) startup grants for supporting entrepreneurial activity and experimentation, (3) involvement of government-owned research institutes in the development and diffusion of knowledge, and, most importantly, (4) differences in regulatory regimes affecting the market formation depending on the operating areas of the shipping companies. Therefore, further studies on environmental innovation should focus, in greater detail, beyond the initial policy "push," on the connections between public policy and the development of the system as an evolutionary process that directs its functioning. This would facilitate - as envisioned by Jacobsson and Bergek (2011) — to devise suitable policy interventions for promoting environmental innovation.

Finally, the paper naturally contains limitations, since it is based on a single environmental innovation. Therefore, comparative research beyond the environmental innovation and industry discussed in this paper are needed to uncover, e.g., whether the heightened importance of public policy also holds for industries that are more clearly 
providing their products to the general public rather than to business customers. Moreover, the data utilized here is qualitative. Quantitative analyses verifying causal relations between the different aspects of the combined SSI/TIS framework would provide further support for the conclusions drawn in this paper. Further studies could work, e.g., on detecting growth patterns in the market demand for environmental innovation after distinct policy interventions and, thus, guide policymakers work in facilitating both business and sustainable development.

Acknowledgments We are grateful to Simo Rautiainen for drawing Fig. 1 and to the anonymous referees for their comments on improving the paper.

Funding Open Access funding provided by University of Eastern Finland (UEF) including Kuopio University Hospital.

\section{Compliance with ethical standards}

Conflict of interest The authors declare that they have no conflict of interest.

Open Access This article is licensed under a Creative Commons Attribution 4.0 International License, which permits use, sharing, adaptation, distribution and reproduction in any medium or format, as long as you give appropriate credit to the original author(s) and the source, provide a link to the Creative Commons licence, and indicate if changes were made. The images or other third party material in this article are included in the article's Creative Commons licence, unless indicated otherwise in a credit line to the material. If material is not included in the article's Creative Commons licence and your intended use is not permitted by statutory regulation or exceeds the permitted use, you will need to obtain permission directly from the copyright holder. To view a copy of this licence, visit http://creativecommons.org/licenses/by/4.0/.

\section{References}

Batista W, Fernandes F, Lopes C, Lopes R, Miller W, Ruiz G (2017) Which ballast water management system will you put aboard. Environments 4:54. https://doi.org/10.3390/environments4030054

Bax N, Williamson A, Aguero M, Gonzalez E, Geeves W (2003) Marine invasive alien species. Mar Policy 27:313-323. https://doi.org/10.1016/S0308-597X(03)00041-1

BEMA (2019) Ballast water Equipment Manufacturers Association. https://bwema.org/. Accessed 9 January 2020

Bergek A, Jacobsson S, Carlsson B, Lindmark S, Rickne A (2008) Analyzing the functional dynamics of technological innovation systems. Res Policy 37:407-429. https://doi.org/10.1016/j.respol.2007.12.003

Blatchley E, Cullen J, Petri B et al (2018) The biological basis for ballast water performance standards. Environ Sci Technol 52:8075-8086. https://doi.org/10.1021/acs.est.8b00341

Bowmer T, Linders J (2010) A summary of findings from the first 25 ballast water treatment systems evaluated by GESAMP. WMU J Marit Aff 9:223-230. https://doi.org/10.1007/BF03195177

C̆ampara L, Frančić V, Maglić L, Hasanspahić N (2019) Overview and comparison of the IMO and the US Maritime Administration ballast water management regulations. J Mar Sci Eng 7:283. https://doi.org/10. 3390/jmse 7090283

Carlsson B, Stankiewicz R (1991) On the nature, function and composition of technological systems. J Evol Econ 1:93-118. https://doi.org/10.1007/BF01224915

Clarksons Research (2017) Ballast water management update. http://www.clarksons.net/docdata/public/ newsdownloads/bwms_update.pdf. Accessed 8 January 2020

Cooke P (2002) Biotechnology clusters as regional, sectoral innovation systems. Int Reg Sci Rev 25:8-37. https://doi.org/10.1177/016001760202500102 
Cullen J (2018) Quantitative framework for validating two methodologies that are used to enumerate viable organisms for type approval of ballast water management systems. Sci Total Environ 627:1602-1626. https://doi.org/10.1016/j.scitotenv.2018.01.302

David M, Gollasch S (2015) Global maritime transport and ballast water management. Springer, Dordrecht

David M, Gollasch S (2018) How to approach ballast water management in European seas. Estuar Coast Shelf Sci 201:248-255. https://doi.org/10.1016/j.ecss.2016.10.018

Davidson I, Minton M, Carney K et al (2017) Pioneering patterns of ballast treatment in the emerging era of marine vector management. Mar Policy 78:158-162. https://doi.org/10.1016/j.marpol.2017.01.021

DNV GL (2019a) Installation of BWTS. https://www.dnvgl.com/news/installation-of-bwts-some-practicalrecommendations-130594. Accessed 23 January 2020

DNV GL (2019b) Type-approved, USCG-compliant ballast water treatment systems. https://www.dnvgl.com/ expert-story/maritime-impact/Ballast-water-management-type-approved-USCG-compliant-treatmentsystems-now-widely-available.html. Accessed 23 January 2020

DNV GL (2019c) Ballast water management. https://www.dnvgl.com/maritime/ballast-water-management/ index.html. Accessed 23 January 2020

European Commission (2010) Europe 2020: a strategy for smart, sustainable and inclusive growth. Brussels.

Flagella M, Abdulla A (2005) Ship ballast water as a main vector of marine introductions in the Mediterranean Sea. WMU J Marit Aff 4:95-104. https://doi.org/10.1007/BF03195066

Galliano D, Nadel S (2015) Firms' eco-innovation intensity and sectoral system of innovation. Ind Innov 22: 467-495. https://doi.org/10.1080/13662716.2015.1066596

Geels F, Hekkert M, Jacobsson S (2008) The dynamics of sustainable innovation journeys. Tech Anal Strat Manag 20:521-536. https://doi.org/10.1080/09537320802292982

Gerhard W, Lundgreen K, Drillet G et al (2019) Installation and use of ballast water treatment systems. Ocean Coast Manag 181:104907. https://doi.org/10.1016/j.ocecoaman.2019.104907

Gopalakrishnan S, Damanpour F (1997) A review of innovation research in economics, sociology and technology management. Omega 25:15-28. https://doi.org/10.1016/S0305-0483(96)00043-6

Gosens J, Lu Y, Coenen L (2015) The role of transnational dimensions in emerging economy 'technological innovation systems' for clean-tech. J Clean Prod 86:378-388. https://doi.org/10.1016/j.jclepro.2014.08. 029

Hämäläinen E, Inkinen T (2019) Industrial applications of big data in disruptive innovations supporting environmental reporting. J Ind Inf Integr 16:100105. https://doi.org/10.1016/j.jii.2019.100105

Hekkert M, Suurs R, Negro S et al (2007) Functions of innovation systems. Technol Forecas Soc Chang 74: 413-432. https://doi.org/10.1016/j.techfore.2006.03.002

Hu S, Liu S (2019) Do the coupling effects of environmental regulation and R\&D subsidies work in the development of green innovation? Clean Techn Environ Policy 21:1739-1749. https://doi.org/10.1007/ s10098-019-01745-6

IMO (2004) International convention for the control and management of ships' ballast water and sediments. http://www.imo.org/en/About/Conventions/ListOfConventions/Pages/International-Convention-for-theControl-and-Management-of-Ships'-Ballast-Water-and-Sediments-(BWM). Accessed 23 January 2020

IMO (2017) Global treaty to halt invasive aquatic species enters into force. http://www.imo.org/en/ MediaCentre/PressBriefings/Pages/21-BWM-EIF.aspx. Accessed 23 January 2020

IMO (2019a) Ballast water management. http://www.imo.org/en/OurWork/Environment/ BallastWaterManagement/Pages/Default.aspx. Accessed 23 January 2020

IMO (2019b) Status of conventions. http://www.imo.org/en/About/Conventions/StatusOfConventions/Pages/ Default.aspx. Accessed 2 January 2020

IMO (2019c) GloBallast programme. http://www.imo.org/en/OurWork/Environment/MajorProjects/Pages/ GloBallast-Programme.aspx. Accessed 9 January 2020

Jacobsson S, Bergek A (2011) Innovation system analyses and sustainability transitions. Environ Innov Soc Transit 1:41-57. https://doi.org/10.1016/j.eist.2011.04.006

King D, Hagan P, Riggio M, Wright D (2012) Preview of global ballast water treatment markets. J Mar Eng Technol 11:3-15. https://doi.org/10.1080/20464177.2012.11020256

Köhler J (2014) Globalization and sustainable development. J Environ Dev 23:66-100. https://doi.org/10. $1177 / 1070496513507260$

Koukaki T, Tei A (2020) Innovation and maritime transport. Case Stud Transp Policy 8:700-710. https://doi. org/10.1016/j.cstp.2020.07.009

Laaksonen E, Mäkinen H (2013) The competitiveness of the maritime clusters in the Baltic Sea Region. J East-West Bus 19:91-104. https://doi.org/10.1080/10669868.2013.780502

Lam J, Zhang X (2019) Innovative solutions for enhancing customer value in liner shipping. Transp Policy 82: 88-95. https://doi.org/10.1016/j.tranpol.2018.09.001 
Makkonen T, Inkinen T (2018) Sectoral and technological systems of environmental innovation. J Clean Prod 200:110-121. https://doi.org/10.1016/j.jclepro.2018.07.163

Makkonen T, Repka S (2016) The innovation inducement impact of environmental regulations on maritime transport. Int J Innov Sustain Dev 10:69-86. https://doi.org/10.1504/IJISD.2016.073413

Makkonen T, Inkinen T, Saarni J (2013) Innovation types in the Finnish maritime cluster. WMU J Marit Aff 12:1-15. https://doi.org/10.1007/s13437-013-0039-4

Malerba F (2002) Sectoral systems of innovation and production. Res Policy 31:247-264. https://doi.org/10. 1016/S0048-7333(01)00139-1

Malerba F, Orsenigo L (1997) Technological regimes and sectoral patterns of innovative activities. Ind Corp Chang 6:83-117. https://doi.org/10.1093/icc/6.1.83

Malerba F, Nelson R, Orsenigo L, Winter S (2007) Demand, innovation, and the dynamics of market structure. J Evol Econ 17:371-399. https://doi.org/10.1007/s00191-007-0060-x

Marine Insight (2019) How ballast water treatment system works. https://www.marineinsight.com/tech/howballast-water-treatment-system-works/. Accessed 3 January 2020

Markard J, Truffer B (2008) Technological innovation systems and the multi-level perspective. Res Policy 37 : 596-615. https://doi.org/10.1016/j.respol.2008.01.004

Marsili O (2002) Technological regimes and sources of entrepreneurship. Small Bus Econ 19:217-231. https://doi.org/10.1023/A:1019670009693

Oltra V, Saint Jean M (2009) Sectoral systems of environmental innovation. Technol Forecas Soc Chang 76: 567-583. https://doi.org/10.1016/j.techfore.2008.03.025

Raza Z (2020) Effects of regulation-driven green innovations on short sea shipping's environmental and economic performance. Transp Res Part D 84:102340. https://doi.org/10.1016/j.trd.2020.102340

Rivas-Hermann R, Köhler J, Scheepens A (2015) Innovation in product and services in the shipping retrofit industry. J Clean Prod 106:443-454. https://doi.org/10.1016/j.jclepro.2014.06.062

Robbins P, O’Gorman C (2015) Innovating the innovation process. R\&D Manag 45:76-93. https://doi.org/10. 1111/radm. 12054

Sassi J, Rytkönen J, Viitasalo S, Leppäkoski E (2005) Experiments with ultraviolet light, ultrasound and ozone technologies for onboard ballast water treatment. VTT Res Notes 2005:2313

Scriven D, DiBacco C, Locke A, Therriault T (2015) Ballast water management in Canada. Mar Policy 59: 121-133. https://doi.org/10.1016/j.marpol.2015.05.014

Seatrade Informa Markets (2020) Sembmarine partners De Nora on ballast water technology retrofits. https:// www.seatrade-maritime.com/asia/sembmarine-partners-de-nora-ballast-water-technology-retrofits. Accessed 10 January 2020

Shi W, Xiao Y, Chen Z et al (2018) Evolution of green shipping research. Marit Policy Manag 45:863-876. https://doi.org/10.1080/03088839.2018.1489150

Silverman D (2016) Qualitative research. Sage, Thousand Oaks

Stehouwer P, Buma A, Peperzak L (2015) A comparison of six different ballast water treatment systems based on UV radiation, electrochlorination and chlorine dioxide. Environ Technol 36:2094-2104. https://doi. org/10.1080/09593330.2015.1021858

UNCTAD (2019) Review of maritime transport 2019. United Nations, New York

US Coast Guard (2019) Ballast water management type approval information. https://www.dco.uscg.mil/OurOrganization/Assistant-Commandant-for-Prevention-Policy-CG-5P/Commercial-Regulations-standardsCG-5PS/Marine-Safety-Center-MSC/Ballast-Water/. Accessed 3 January 2020

Veldhuis M, Hallers C, de la Rivière E et al (2010) Ballast water treatment systems. WMU J Marit Aff 9:213222. https://doi.org/10.1007/BF03195176

Wang Z, Corbett J (2020) Scenario-based cost-effectiveness analysis of ballast water treatment strategies. Manag Biol Invasions 11 in press

Wärtsilä (2014) Ballast water management. https://cdn.wartsila.com/docs/default-source/product-files/bwmsfiles/brochure-o-aquarius-technology.pdf. Accessed 10 January 2020

Yigitcanlar T, Inkinen T (2019) Geographies of disruption. Springer, Cham

Publisher's note Springer Nature remains neutral with regard to jurisdictional claims in published maps and institutional affiliations. 